\title{
高精細多階調カラー画像印刷用薄膜熱転写ヘッドの検討*
}

\author{
寺尾博 年*1, 中谷 壽 ${ }^{* 2}$, 対 馬 \\ 白川享志*2, 日比野 郁夫*2, 新田

\section{Study on a Thin Film Thermal Print Head for High Definition Multi-Level-Tone Color Imaging Use}

\author{
Hirotoshi TERAO*4, Toshifumi NAKATANI, Noboru TSUSHIMA, \\ Takashi SHIRAKAWA, Ikuo HIBINO and Isami NITTA \\ ${ }^{* 4}$ ENGINEERING DEPT. 3, ALPS ELECTRIC CO., LTD, \\ 41-25 Aza Yanagimachi, Noda, Onahama, Iwaki-shi, Fukushima, 971-8615 Japan
}

\begin{abstract}
We studied a 600 dpi high definition thermal print head. Fast thermal response, thermal resistance, uniform contact pressure on print media, and micro process are necessary to achieve $600 \mathrm{dpi}$ high definition thermal transfer print. Therefore, we examined a new structure of a low thermal diffusivity layer on a high thermal diffusivity substrate, and optimum new design of the head shape. As a result, we could drive a $600 \mathrm{dpi}$ thermal print head at high speed and high duty. We studied thermal print head to achieve multi-level tone in thermal transfer printing, which required appropriate heat control of heating elements on the head and varying the amount of resin ink melted by the energized head edge, that is, varying dot diameter as needed. After a series of examination, we came to the conclusion that head form especially the part between a heating elements and head edge is deeply related to the property of the tone. This meant that optimization of the head form was the key to the solution. Thus we have attained multi-level-tone printing by varying dot diameter in 16 levels with the enhanced print head.
\end{abstract}

Key Words: Machine Element, Tribology, Design, Heat Conduction, Thermophysical Property

\section{1. 緒}

熱転写方式のプリンタは, 安価でコンパクトなどの 特長から, 日本語ワープロまたはパソコン用出力機器 として使机てきた. 最近ではデジタルスチルカメラ 用の小型携帯型プリンタとしても熱転写方式が採用さ れている. デジタルスチルカメラの画像出力用プリン タには写真画質に迫る高精細と高速印刷が必要とされ ている．熱転写方式は，図1に示すように，インクリ ボン上の固体インクと紙をサーマルッッドにより直接 加圧した上で，同時に印刷したい部分を加熱すること でイインクを紙の最表面ににじむことなく定着する印 刷方式である. 従って，この印刷工程においては，サ 一マルヘッドの接触圧力や加熱したときのインクの溶 融具合が大変重要になってくる. 著者らはこれまで接 触圧力分布の粘弾性解析を行い, サーマルヘッドの接 触圧力分布を初めて明らかにした(1).またサーマルへ

* 原稿受付 2005 年 5 月 20 日.

*1正員,アルプス電気(株) (画971-8615 いわき市小名浜野田 字柳町 41-25)

*2 アルプス電気 (株)

*3 正員, 新潟大学大学院自然科学研究科(画950-2181 新潟市 五十嵐 2 の町 8050)

E-mail : teraohit@alps.co.jp
ッドで発生した熱は印刷用紙を通して逃げる為，印刷 用紙の熱云導特性も問題になるが，この簡便な評価法 を開発した(2)、しかしながら高精細か心高速印刷を達 成するにはサーマルヘッドの発熱体の微細化並びに加 熱駆動周波数を上げると同時にその周波数に追随寸る サーマルヘッドの高速熱学答特性を達成する必要があ る(3)(6).

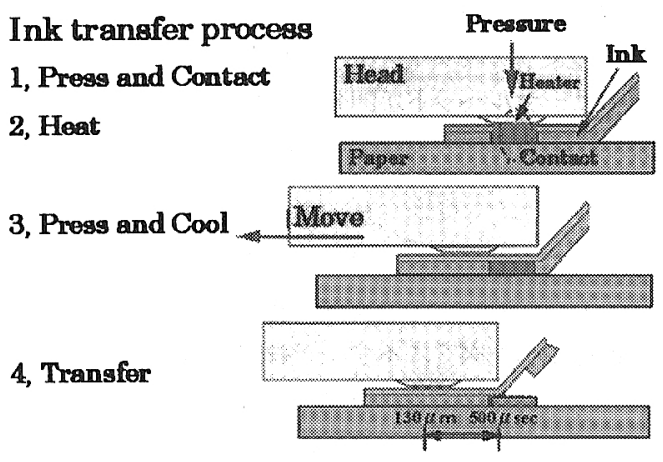

Fig.1 Details of ink transfer process 
図 2(a)に示すように, 10inch/sec（以下 IPS）のーッ ド速度で解像度 400dot/inch（以下 dpi）で印刷を行う 場合はへッドの加熱を $4 \mathrm{kHz}$ で行うことになる.この 場合サーマルヘッドの温度は $4 \mathrm{kHz}$ の駆動周波数に追 随するために所定のドットサイズで印刷することがで きる. 解像度を $600 \mathrm{dpi}$ に上げるには少一マルヘッド の加熱の駆動周波数を $6 \mathrm{kHz}$ とし，この周波数でへッ ドの発熱体を ON/OFFさせる必要がある. しかし，こ の条件ではサーマルヘッド基板が蓄熱するために所定 のドット径が大きくなり, 図 2(b)のように連続した 印刷ドットの間がつぶれてしまう結果となる.

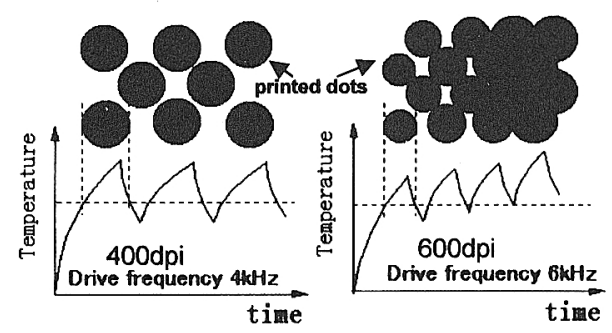

Fig.2 Relation between driving frequency and print image

この問題を解決するために, 単に基板の放熱性を改 善することも考えられるが，逆に急激な昇温のために は膨大な熱エネルギーを発生させなければならなくな る. 小さなエネルギーで急速な昇温と急速な冷却を実 現するためには，熱拡散率の高い材料上に熱拡散率の 低い保温層を形成した基板が必要となる.

そこで, 本研究では熱拡散率の観点からサーマルヘ ッド材料の検討を行った.さらに, サーマルヘッドの 形状の最適化を行った結果 $10 \mathrm{IPS}$ の速度で600dpi の印 刷が可能となったので，そのことについて報告する.

従来の熱転写方式ではドット径を制御することがで きないため, 多階調印刷ができなかった. しかし，本 研究のような高サイクルの加熱冷却を安定して実現で きるサーマルヘッドが開発できれば，多階調印刷も可 能となる. 本研究ではその性能評価も行った.

\section{2. 実 験}

$2 \cdot 1$ サーマルヘッドの構造サーマルヘッド の断面構造を図 3 に示す。一般的なサ一マルッッドの 構造は，ヒートシンク並びに支持体としての絶縁基板 上（アルミナセラミック）に，保温層としての熱絶縁 層（グレーズ）が形成され，更にこの表面上に発熱体，

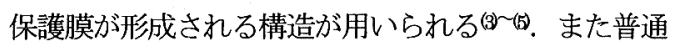
紙上にレジンインクを強固に押しつけるために, 直線
状の凸状突出部をつくり，この頂上に発熱体を形成す る.こうすることでサーマルヘッドに加えた荷重を発 熱体部に集中させることができる(1). 熱転写方式での インク転写において，インクをインクリボンのベース フィルムから剥離させる場合, 発熱体からへッドのエ ッヂまでの距離, いわゆるエッヂ距離によって転写特 性が大きく変化することが知られている(熱転写方 式で高速か力高密度で印刷するには，高速な熱空答性 がサーマルヘッドに要求されるため, 従来のアルミナ セラミックよりも熱拡散率が高い基板をベースに使い， グレーズよりも熱拡散率の低い保温層を薄く形成すれ ばよいことになる，表 1 に種々の材料の熱拡散率を示 す.

$2 \cdot 2$ 試作へッドの構造 本研究に使用したへ ッドの断面構造を図 3 に示す. 解像度を $600 \mathrm{dpi}$ とす るために 240 ドットの発熱体を $42 \mu \mathrm{m}$ ピッチで紙面 に垂直方向に一列にならべ，一度に 0.4 インチの幅で 印刷できるシリアル型熱転写プリンタ用ヘッドである. ヘッドの外形寸法は $18 \mathrm{~mm} \times 8.5 \mathrm{~nm} \times 0.8 \mathrm{~nm}$ である.

本研究ではサーマルヘッドのベース基板として, 単 結晶 Si ウェハーを選択した。.それは, 熱拡散率がア ルミナセラミックに対し 6 倍高く, かつ表面が平滑で 600dpi の配線パターンを安定して形成寸ることができ るためである. 保温層は従来のグレーズに対し, 種々 の成膜条件で低密度柱状構造の薄膜を作製し，その性 能を調べた.

今回試作したヘッドでは，直線状の凸状突出部の高 さを約 1.5 倍にし，かつ平坦部と突出部頁面までの斜 面の角度も約 1.5 倍としている. またエッジ距離を約 60〜150 $\mu \mathrm{m}$ に変化させ，インク転写に及ぼす影響を 調べた.

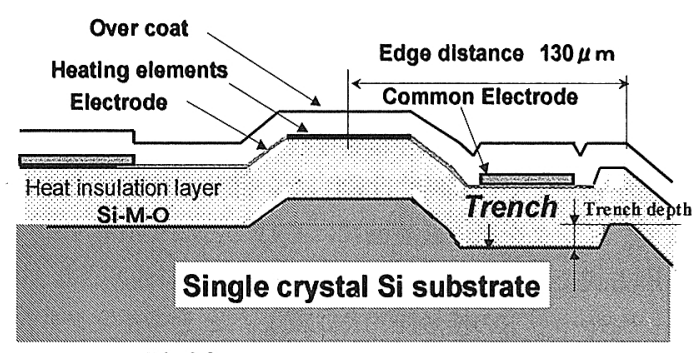

Fig,3 Structure of a thermal print head

Table.1 Thermal diffusivity of various materials

\begin{tabular}{|c|c|}
\hline Material & Thermal Diffusivity $\left(\mathrm{mm}^{2} / \mathrm{s}\right)$ \\
\hline Alumina ceramics & 12.1 \\
\hline Single crystal Si & 72.6 \\
\hline Glaze & 0.45 \\
\hline SiO2 sputtered film & 0.89 \\
\hline Heat insulation kayer & 0.39 \\
\hline
\end{tabular}


$2 \cdot 3$ 印刷の実験条件 本研究のヘッドを市販の 熱転写プリンタ（MD5500 アルプス電気製）に搭载し， 専用紙を用いて印刷を行った. 使用した印刷速度とへ ッドの押しつけ圧力，並びに投入電力は $254 \mathrm{~mm} / \mathrm{sec}$ と 6. OMPa， 0.26W/dot とした. 印刷実験に用いたパター ンは，1ドットの周冊が必ず空白となる面積率 $25 \%$ のパターンを用いた。

$2 \cdot 4$ 印刷濃度と階調性評価 印刷浱度測定には 反射濃度計 RD918（マクベス社製）を使用した．階調 性評価には，入力デー夕の階調值を变えて印刷し，そ の印刷濃度を測定して比較を行った。

$2 \cdot 5$ ヘッド熱応答測定 ヘッドの熱応答特性の 評価には赤外線顕微鏡型放射温度計：RM2A（日本バー ンズ製）にて対物レンズ 36 倍を用いて測定をおこな った．熱応答波形比較では投入電力を $0.26 \mathrm{~W} / \mathrm{dot}$ と した.

\section{3. 実 験 結 果}

$3 \cdot 1$ 保温層の検討 サーマルヘッド基板材料は 単結晶 Si であるが，その上に形成する熱拡散率の低 い保温層材とその形成方法を検討した。

本研究では保温層材の作製力法として，ターゲット 材に Si や金属等を使い，酸素ガス中でスパッタリン グする，いわゆる反応性スパッタリング法を採用した. 熱拡散率を表 1 に示しているが，グレーズ保温層の $0.45\left(\mathrm{~mm}^{2} / \mathrm{s}\right)$ に対し, Si 合金酸化膜のスパッタ保温層は $0.39\left(\mathrm{~mm}^{2} / \mathrm{s}\right)$ と約 $15 \%$ 熱拡散率が低くなっている.

スパッタリングを採用したことで，成膜条件により さまざまな密度の膜が形成できる. 図 4 に成膜条件の 違いによる構造の変化を示した，成膜ガス圧が高くな るに従い，低密度の柱状構造になっていく様子が分か る. 密度が変化することで熱学答特性も変化する. 図 5 に成膜ガス圧に対寸るへッド発熱温度の変化を示し た. ガス圧が高いほど，発熱温度が高くなることが分 かる. 本研究では熱応答特性と再現性を考虑し，成膜 圧力は約 $1 \mathrm{~Pa}$ とした.

また，反応性スパッタリングを採用した理由は，成 膜速度を上げる為である．スパッタリング法は厚膜印 刷法や塗布法等に比べ，成膜速度が遅いため生産性が 悪く $\mathrm{SiO}_{2}$ のような絶縁物を使った場合は特に遅くな るからである. 反応性スパッタリングの採用により $\mathrm{SiO}_{2}$ をターゲット材料とした場合に比べ，成膜速度は 約 3 倍となった。

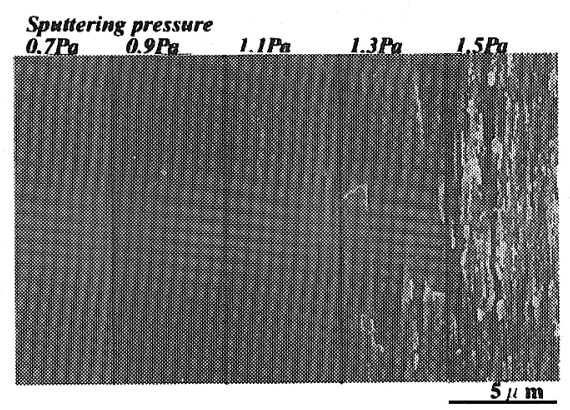

Fig.4SEM image of heat insulation layer

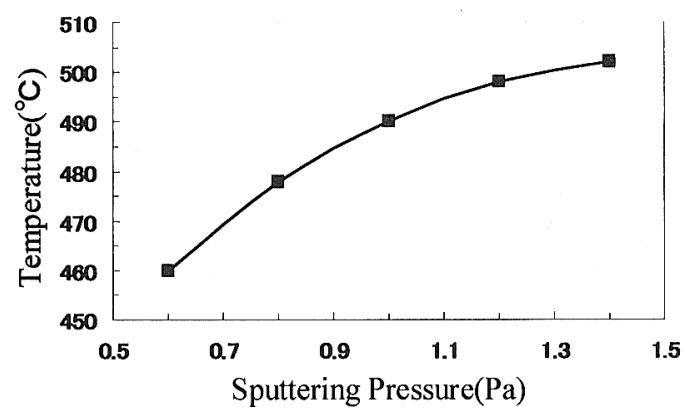

Fig.5 Relation between sputtering pressure and head temperature

3 -2 熱応答特性 Si 基板ならびにスパッタ保 温層を採用した本研究のヘッド熱応答特性を測定した. 単独パルスの測定において, 従来へッドに比べ本研究 のヘッドは同一温度到達時間で比較した場合, 約 $20 \%$ 速い応答性を示した。これは保温層熱拡散率が従 来ヘッドより低いためと考えられる.

また図 6 に連続パルスを与えた場合の測定結果を示 すが, 従来へッドに比べ, 基板での蓄熱による温度上 昇もなく，高速高密度駆動に対応していることがわか る.これはヘッド基板の熱拡散率が従来の 6 倍も大き いためと考えられる.

$\mathbf{3} \cdot \mathbf{3}$ 多階調印刷 一方, 熱転写方式において多 階調印刷を実現するためには，1 ドットのドット径を 従来よりも小さくし，かつその径を制御する必要があ る. またドット径を小さくした場合の転写ドットの安 定性が連綕階調にとっては不可欠であり，そのために はインクを十分に定着させなければならない.

四 7 にドット径を変化させる場合のヘッド温度とイ ンク温度，そのときのドット径の関係を模式図で示し た. 図 1 に示したように, 熱転写方式でのレジンイン クの転写プロセスは大きく分けて 4 工程からなるわ. 
印刷速度 10IPS，駆動周波数 6kHz であるため，この一 連の工程が時閒にして $500 \mu \mathrm{sec}$ ，距離にして $130 \mu \mathrm{m}$ で行われることになる.ここで, ヘッドエッナ゙部にて インクがベースフィルムより剥離される時点で, 図 7 に示すように, ヘッド温度を下げ, 転写ドット部のレ ジンインクの温度を低くすることにより，ドット径を 小さくすることができる. しかし，従来へッドにてへ ッド温度を下げて印刷すると, 転写されたレジンイン クは図 8(a)に示すように尾を引いた形となり不安定 な転写状熊となる. 一方, 本研究で試作したサーマル ヘッドを用いると，図 8(b)に示すようにドット径を 小さくできることが確認された.

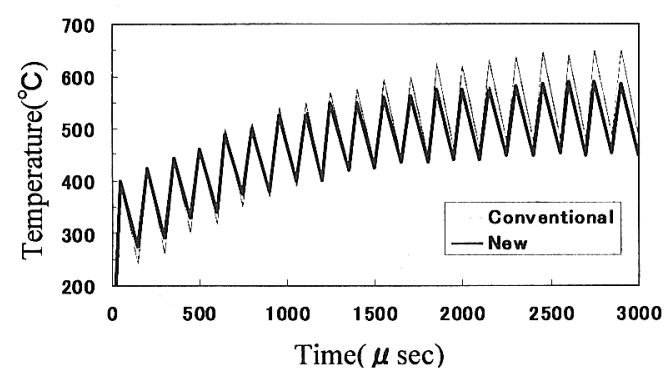

Fig.6 Head peak temperature of continuation pulse

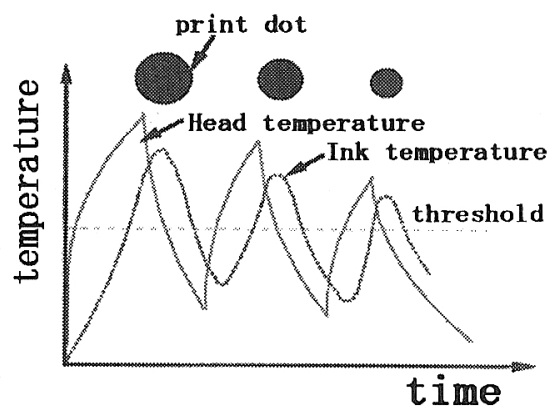

Fig.7 Relation between dot diameter and head temperature or ink temperature

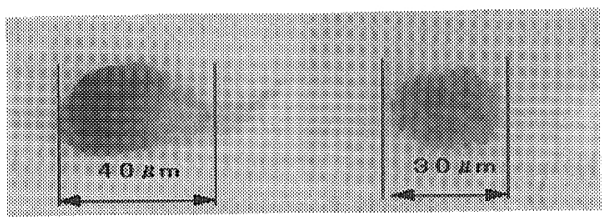

(a)Conventional

(b) New
3・4 ヘッド形状検討 インク転写の安定性を検 討する目的で，ヘッドの発熱体からヘッドエッヂまで の形状を変更して検討を進めた．具体的には下記表 2 に示すように，発熱体からへッドエッヂまでのエッヂ 距離と発熱体からエッデまでの間に溝を形成した場合 のその深さを変えて比較を行った.

Table.2 Head shape of each sample

\begin{tabular}{|c|c|c|}
\hline No & Edre distance $(\mu \mathrm{m})$ & Tranch depth $(\mu \mathrm{m})$ \\
\hline 1 & 60 & 0 \\
\hline 2 & 80 & 0 \\
\hline 3 & 100 & 0 \\
\hline 4 & 120 & 0 \\
\hline 5 & 130 & 0 \\
\hline 6 & 140 & 0 \\
\hline 7 & 150 & 0 \\
\hline 0 & 130 & 2 \\
\hline 8 & 130 & 3 \\
\hline 10 & 130 & 4 \\
\hline 11 & 130 & 5 \\
\hline
\end{tabular}

エッヂ距離を変更した場合の印刷評価結果を図 9 に 示す.この検討では印刷濃度だけでなく，印刷インク の紙との密着性を評価する目的で消しゴムにて 10 回 摺動した後の濃度测定結果も示した。図9より，ヘッ ドエッヂ距離が短ければ短いほど，印刷濃度が高い傾 向を示すことがわかる. 一方，インクの紙への定着性 をみると，エッヂ距離に最適值があることが分かり， この印刷条件では $130 \mu \mathrm{m}$ 付近が最適值であることを 示している. またその最適範囲も $130 \mu \mathrm{m}$ 対して士 $5 \mu \mathrm{m}$ 程度である.

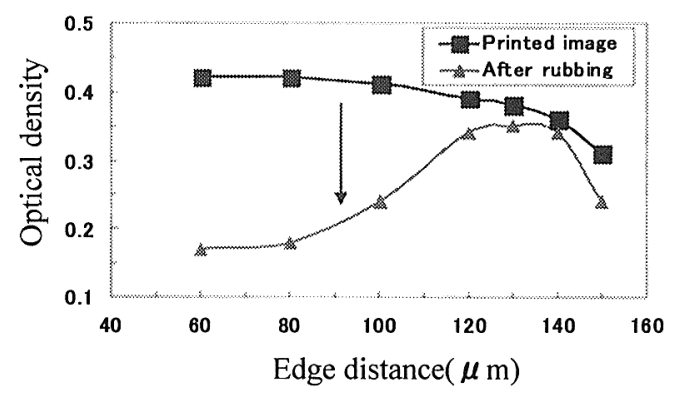

Fig.9 Relation between edge distance and print density and relations between edge distance and rubbing-resistance

溝樑さを変更した場合の印刷評価結果を図 10 に示 す.この検討では印刷濃度だけでなく，印刷走行状態 を示すスリップ率も示している. スリップ率とは下記 
に示寸式(1)の通りであり，值が小さいほど, インク の走行が安定であることを示す.

Slip ratio $(\%)=100-\frac{\text { Ink spent length } \times 100}{\text { Print length }}$

図 10 より, 転写ドットの安定性加溝媣さは $2 \mu$ $\mathrm{m}$ 以上が必要であることが分かる. また逆に $4 \mu \mathrm{m}$ 以 上の場合，スリップ率が増加し，インクリボンの搬送 に不具合が生じてくることが分かる.よって，溝の形 成には $3 \mu \mathrm{m} \pm 1 \mu \mathrm{m}$ の加工精度が必要であることが 分かる.

このへッドを使用した印刷結果を図 8(b)に示した. 従来へッドに比べて，レジンインクが安定に転写され ていることが分かる．また同時にシャドー部（ドット 径の大きいところ）では，印刷のつぶれも緩和された。

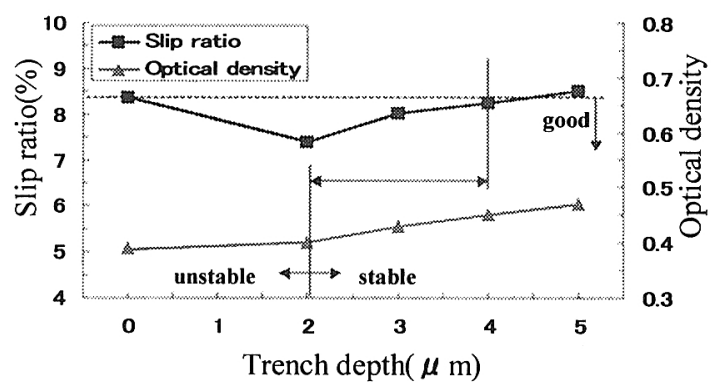

Fig.10 Rebation between trench depth and optical density or slip ratio

$$
\rho c\left(\frac{\partial T}{\partial t}+v_{x} \frac{\partial T}{\partial x}+v_{y} \frac{\partial T}{\partial y}\right)+k \frac{\partial^{2} T}{\partial x^{2}}+k \frac{\partial^{2} T}{\partial y^{2}}=Q
$$

$\begin{array}{ll}\rho & \text { Density } \\ \mathbf{c} & \text { Specific heat } \\ \mathbf{T} & \text { Temperature } \\ \mathbf{t} & \text { Time } \\ \mathbf{V} \mathbf{x}, \mathbf{V y} & \text { Velocity of a moving fluid } \\ \mathbf{k} & \text { Thermal conductivity } \\ \mathbf{Q} & \text { Generation of heat }\end{array}$

Table 3 Material properties

\begin{tabular}{|c|c|c|c|}
\hline Materkals & \begin{tabular}{|c|} 
Tharmol \\
conductivity \\
$\lambda(\mathrm{w} / \mathrm{mK})$ \\
\end{tabular} & 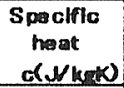 & 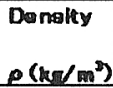 \\
\hline Si substrate & 150 & 105 & 2330 \\
\hline Hagt Insulatlon layer & 1.2 & 1000 & 100 \\
\hline Meator & 45 & 700 & 6 \\
\hline Over coat & 3 & 1000 & 320 \\
\hline PET & 0.14 & 1340 & 140 \\
\hline Peralfin & 0.32 & 2520 & \\
\hline Ink & 0.348 & 2440 & 86 \\
\hline Paper & 0.00 & 1170 & 105 \\
\hline
\end{tabular}

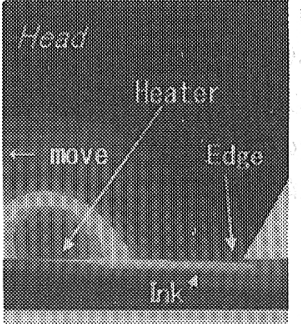

(a)Conventional



(b) New
Fig,11 Simulated thermal distribution

\section{4. 考察}

ヘッド形状を変更した場合インク転写状態が改善 された. その原因を調べるために，ヘッド発熱体から インクが転写されるヘッドエッヂ部までのインクの温 度分布解析を汎用有限要素解析ソフト ANSYS (Ver6. 1) を使用して 2 次元問題として行った. 解析に用いた境 界条件は，サーマルヘッド，並びに，媒体表面の境界 面に熱伝達率をあたえ，空気中へ熱伝達するモデルと した. またヘッドとインクリボンの接触部には $0.2 \mu$ mの空気層を入れた計算とし，実験との調整をおこな った．使った式は式(2)の通りであり，入力した熱物 性值は表 3 に示寸通りである. 図 11 にF EM解析に よるヘッドとインクの温度分布を示した.

図11(a)は従来へッドについての結果である. 発熱 体からエッヂ部までの間にインク温度のピークが見ら れる.これより，インクの熱がヘッド発熱部とエッヂ 部の間の接触部分でヘッド側に逃げ，そのためエッヂ 部で温度が下がっていることが分かる。このことが原 因で，ハイライト部分（ドット径が小さいところ）に おいてインクの転写が不安定となっていたと考えられ る.

次に,ヘッド発熱体からエッヂまでの間で, インク の熱がヘッド側に逃げないようにするため、コモン電 極を溝に埋め込む構造にて熱解析を行った。この結果 を図 11 (b)に示寸，この場合は，ヘッド発熱部とエッ ジ部の間で必要以上にインクの熱がヘッド側に逃げる ことがなくなり，レシシシインクがベースフィルムから 剥離されるヘッドのエッヂ部にてインク温度がピーク を示している.よって，多階調印刷を行うためには、 発熱体からエッヂまでの間でインクの熱がヘッド側に 逃げにくい形状設計をすればよいことがわかる．130 $\mu \mathrm{m}$ のエッヂ距離が最適值を示した理由もこのインク の温度とへッドの走行が関係していたこともこの解析 からわかった. すなわち，インク内の温度がピークを むかえるのが，発熱体から $130 \mu \mathrm{m}$ 離れた位置である ということである. 
以上で明らかになったように, サーマルヘッドには 高い加工精度が要求される. 必要なへッド形状加工に ついては, 単結晶 Si 基板の異方性エッチングにより 達成している.あらかじめ凸状の突出部を異方性エッ チングにて加エし，その後, 满部分を同様に異方性エ ッチングにて加工することで, 加工誤差を $\pm 1 \mu \mathrm{m} に$ 抑えることができた。

図 12 に階調值に対する，印刷濃度の関係を示す。 横軸は発熱体に入力寸る電力の大きさを示している. 図 12 より，0〜20\%のハイライト部分では, 従来へッ ドの場合は 0 ～10\%まで印刷濃度の上昇が見られなか ったが，本へッドでは濃度が徐々に上がっている。一 方 90\% 100\%のシャドー部分では, 従来は 90\%でほ ぼ濃度が飽和仕切っていたが，本へッドでは 90\%〜 $100 \%$ の間でも濃度の上昇が見られた。従って従来一 ッドの場合実質 10\%〜90\%までの 80\%の閒の階調表 現しかできなかったが，本ヘッドの場合，0〜100\%ま での階調表現ができ，階調特性が向上したことが分か る. 図 13 に印刷結果の比較を示す.この図は自然画 のハイライト部分を拡大した図である. 図 13 (a) は従 来ヘッドで印刷した場合であり， 2 值の面積階調によ る印刷, 図 13(b)は本へッドによる多階調印刷の結果 であるが, この画像比較によっても, 本へッドによっ て階調特性が向上したことが分かる.

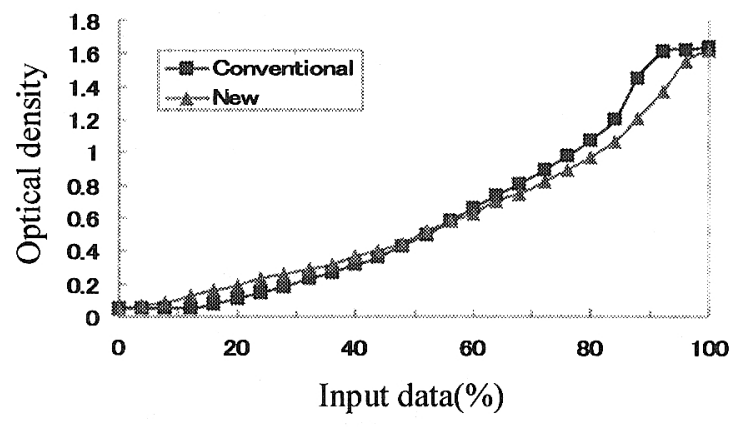

Fig.12 Tone reproduction curve of new head

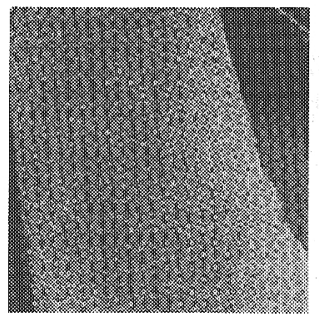

(a)Conventional

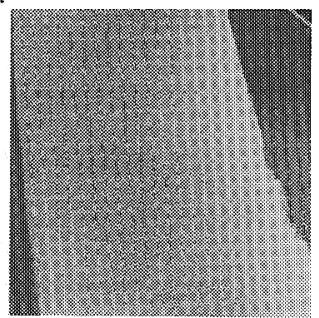

(b) New
Fig.13Comparison with printed image

\section{5. 結 論}

本研究では，熱転写方式にて高速，高精細印刷を可 能とするために，熱拡散率の観点からサーマルッッド 材料の検討を行った. さらに, サーマルッッドの形状 の最適化を行った結果，以下のことが実現できた。

（1）高熱拡散率の単結晶 Si 基板の上に，低熱拡散率 層をスパッタで形成した結果， 600dpi のサーマ ルヘッドを高速に高密度で駆動でき，熱転写方式 にて速度 10IPS，解像度 600dpi の印刷が実現でき た.

（2）発熱体からへッド端部までの間のヘッド形状が階 調特性に影響することが分かった. ヘッド形状を 最適化することで, 1 ドットの径を 16 段階に変 化させることができ，レジンインクを用いた熱転 写方式での多階調印刷が実現できた.

\section{文献}

(1) Nitta, L, Terao, H, Seshita, T., Analysis of contact pressure acting on a thermal print head of a thermal transfer printer, Transactions of the Japan Sacietyof Mechanical Engineers, Series CY Vol. 70, №.693 (2004), pp. 258-263.

(2) Nitta, L, Terao, H, Seshita, T., Evaluation of'Thermal Conductivities of Printing Papers Using a Thermal Transfer Printer, Joumal of the Japan Society of Precision Engineering, Vol 70, 4(2004), 522.

(3) Nagata, T., Sato, K, Watanabe, M., Pulse Durability Characteristics of Thin-Film Thermal Head, Transactions of the Japan Society of Mechanical Engineers, Series C, Vol 62, No.601 (1996), pp. 56-61.

(4) Nagata, T., Sato, K, Watanabe, M, Printing Characteristics Estimation of Thermal Head, Transactions of the Japan Society of Mechanical Engineers, Series B, Vol 61, No.581 (1995), pp. 286-294.

(5) Nagata, T., Watanabe, M., 16dots/mm thermal printing head developing heat efficiency with polyimide heat insulating layer. Transactions of the Japan Society of Mechanical Engineers, Series B, Vol. 61, No.585(1995), pp. 286-291.

(6) Murata, A., Mochizuki, S., Morimoto,Y,Fgashira,N., Printing Characteristics of Full-Color Thermal Dye-Transfer Printers Using Semiconductor Laser Heat. Transactions of the Japan Society of Mechanical Engineers, Series B, Vol 61, No.582 (1995), pp. 328-333.

(7) Hibino,L,Ono,S.,Uchida,T., Study of Highdefinition Thermal Transfer Process. Transactions of the Institute of Electonics, Information and Communication EngineersVOL J81-C-2NO. 6:PAGE. 566-573; (1998106) 